\title{
Family Health Nursing
}

National Cancer Institute

\section{Source}

National Cancer Institute. Family Health Nursing. NCI Thesaurus. Code C18790.

General and comprehensive nursing practice directed to families. Often involves home visits. 